OPEN ACCESS

Edited by:

Juliet Spencer,

Texas Woman's University,

United States

Reviewed by:

Vijayakumar Velu,

Emory University, United States

Cristian Apetrei,

University of Pittsburgh, United States

*Correspondence:

R. Keith Reeves

rreeves@bidmc.harvard.edu

Specialty section: This article was submitted to

Viral Immunology,

a section of the journal

Frontiers in Immunology

Received: 22 September 2018 Accepted: 20 November 2018

Published: 04 December 2018

Citation:

Manickam C, Shah SV, Lucar O, Ram DR and Reeves RK (2018)

Cytokine-Mediated Tissue Injury in Non-human Primate Models of Viral Infections. Front. Immunol. 9:2862.

doi: 10.3389/fimmu.2018.02862

\section{Cytokine-Mediated Tissue Injury in Non-human Primate Models of Viral Infections}

\author{
Cordelia Manickam ${ }^{1}$, Spandan V. Shah ${ }^{1}$, Olivier Lucar ${ }^{1}$, Daniel R. Ram ${ }^{1}$ and \\ R. Keith Reeves ${ }^{1,2 *}$ \\ ${ }^{1}$ Center for Virology and Vaccine Research, Beth Israel Deaconess Medical Center, Harvard Medical School, Boston, MA, \\ United States, ${ }^{2}$ Ragon Institute of Massachusetts General Hospital, MIT and Harvard, Cambridge, MA, United States
}

Viral infections trigger robust secretion of interferons and other antiviral cytokines by infected and bystander cells, which in turn can tune the immune response and may lead to viral clearance or immune suppression. However, aberrant or unrestricted cytokine responses can damage host tissues, leading to organ dysfunction, and even death. To understand the cytokine milieu and immune responses in infected host tissues, non-human primate (NHP) models have emerged as important tools. NHP have been used for decades to study human infections and have played significant roles in the development of vaccines, drug therapies and other immune treatment modalities, aided by an ability to control disease parameters, and unrestricted tissue access. In addition to the genetic and physiological similarities with humans, NHP have conserved immunologic properties with over 90\% amino acid similarity for most cytokines. For example, human-like symptomology and acute respiratory syndrome is found in cynomolgus macaques infected with highly pathogenic avian influenza virus, antibody enhanced dengue disease is common in neotropical primates, and in NHP models of viral hepatitis cytokine-induced inflammation induces severe liver damage, fibrosis, and hepatocellular carcinoma recapitulates human disease. To regulate inflammation, anti-cytokine therapy studies in NHP are underway and will provide important insights for future human interventions. This review will provide a comprehensive outline of the cytokine-mediated exacerbation of disease and tissue damage in NHP models of viral infections and therapeutic strategies that can aid in prevention/treatment of the disease syndromes.

Keywords: viral infections, cytokines, animal model, tissue damage, non-human primates

\section{INTRODUCTION}

Microbial pathogens are constantly evolving to evade the host's immune system, and even with several decades of research and modern therapeutics, chronic diseases such as those caused by human immunodeficiency virus (HIV-1) and hepatitis C virus (HCV) are still globally prevalent. Viruses use multiple evasive strategies such as avoiding detection by pattern recognition receptors, $\mathrm{T}$ cell receptors and antibodies, mimicking or blocking cytokines, chemokines and other host proteins, and/or directly depleting immune cell subsets [reviewed in (1)]. Disruption of the cytokine milieu is also an important and commonly used strategy by viruses (2-4), since cytokines play important roles in shaping both innate and adaptive immunity. Cytokines are soluble proteins 
secreted by cells during inflammation that act as key mediators of immune cell recruitment and modulators of the immune response via a complex network of cellular interactions and signaling pathways. So far, more than 300 cytokines including chemokines, interferons (IFN), and lymphokines have been described (5). While cytokines can be broadly classified based on the nature of the immune response as pro-inflammatory cytokines such as interleukin (IL)-1, IL-6, type 1 IFN, tumor necrosis factor (TNF)- $\alpha$, and anti-inflammatory cytokines such as IL-4, IL-10, and transforming growth factor (TGF)- $\beta$, they have pleiotropic functions whereby individual cytokines can have either pro- or anti-inflammatory properties according to the cell system involved.

In viral infections, cytokines play central roles in the development of protective anti-viral responses, but also potential immunopathology associated with chronic viral diseases. Viral interactions with host cellular receptors triggers proinflammatory cytokine secretion which are essential for viral clearance. However, dysregulations in the cytokine type and quantitative levels can lead to overactivation of immune cells, which in turn cause tissue damage leading to fatal complications. For instance, extensive characterization of IFN- $\alpha$ and its direct antiviral activity since its discovery in 1957 (6), has led to successful treatment of "non-A, non-B (NANB) hepatitis" even before the actual identification of $\mathrm{HCV}$ as the causative agent (7). Combination therapy of pegylated IFN- $\alpha$ with ribavirin was the standard therapeutic regime for chronic HCV-infected patients until the recent introduction of directly acting antivirals. However, IFN- $\alpha$ therapy can induce side effects such as fever and headache to severe life threatening conditions including thyroid, visual, auditory, renal and cardiac impairments, and pulmonary interstitial fibrosis (8). The therapeutic use of cytokines for infectious diseases, autoimmune diseases and malignancies, may also come at a steep price, since prolonged use of cytokines present severe side-effects due to the pleiotropic nature of these molecules $(9-14)$. While, it is necessary to understand cytokine dysregulations in viral diseases to anticipate potential tissue injury and deterioration, their pleotropic, rapid, and in some cases local and long term tissue effects make the study of cytokines in humans challenging with potential development of fatal complications. These challenges can be met by the use of animal models. Animal models have been used since more than 2400 years and currently are employed in all areas of biomedical research including basic biology, infections, immunology, cancer, metabolic diseases, and behavioral studies (15). This review is primarily focused on the virus mediated cytokine dysfunctions in animal models specifically non-human primates (NHP), which are already fundamental in the validation of human data.

\section{NEED FOR ANIMAL MODELS IN STUDIES OF VIRAL IMMUNITY}

Much of what is known regarding antiviral immunity and tissue inflammation comes from studies conducted in animal models of human diseases. Animal models act as preclinical and translational gatekeepers since they allow the study of cellular interactions in vivo and elucidation of disease pathogenesis in tissues that may be difficult to access in humans. While mouse models have provided tremendous benefits to immunologists in understanding immune responses in humans, 65 million years of divergent evolution has contributed to significant differences in cytokines and cytokine receptors for the two species. Studies have shown poor correlation in genomic responses to acute inflammatory stress between humans and mice (16), and engagement of different chemokine/cytokine pathways in response to oxygen and glucose deprivation by human neurons compared to murine neurons (17). IL-13 seems to induce B cell class switching for IgE production specifically in humans whereas mice require IL-4 $(18,19)$. Similarly, IL-7 receptor deficiency inhibits development of all T and B lymphocytes in mice (20), but only $\mathrm{T}$ cells in humans (21). Furthermore, a number of pathogens like influenza, HIV, or dengue are highly tropic to their respective hosts and do not mimic human pathologies in mice, potentially restricting the use of mice as models for some infectious diseases [reviewed in (22)].

NHP are perhaps the most commonly utilized models to study and understand immune responses against human infectious agents and for preclinical evaluation of therapeutics and vaccines (Figure 1). NHP have proven essential for research breakthroughs in maladies such as cancer, Parkinson's disease, heart diseases, and various infectious diseases such as HIV, Zika, Ebola, influenza, and others (23, 24). Even though NHP research accounts for $<1 \%$ of the all the biomedical laboratories working in animal models (24), the advantages offered by NHP due to the genetic and physiological homology to humans are manifold. Indeed, human and NHP cytokines are relatively conserved with $95 \%$ amino acid identity of most cytokines such as IL-2 and IFN- $\gamma$ for Old World NHP and up to $90 \%$ amino acid identity for New World NHP (25). In addition, many cross reactive reagents and monoclonal antibodies for the detection of cytokines have been evaluated and validated for NHP species (NIH Non-human Primate Reagents Resource; http://www.nhpreagents.org) (25-28), making NHP attractive animal models to study viral pathogenesis and disease progression.

\section{NHP MODELS COMMONLY USED FOR VIRAL DISEASES}

\section{Great Apes}

The great apes used previously as animal models include chimpanzees (Pan troglodytes), and to a lesser extent orangutans (Pongo pygmaeus) and gorillas (Gorilla beringei) (29). Chimpanzees share $>98 \%$ DNA sequence homology to humans; and yet surprisingly, have immune systems that respond much more robustly to infections like HIV and hepatitis B virus (HBV). HBV and HCV can only pathogenically infect humans and chimpanzees, thus making chimpanzees, at one time, the primary animal model for therapeutics and vaccine research (30-32). However, the use of great apes in biomedical research has become increasingly restricted for ethical and cost reasons and therefore other NHP models are being increasingly utilized. 


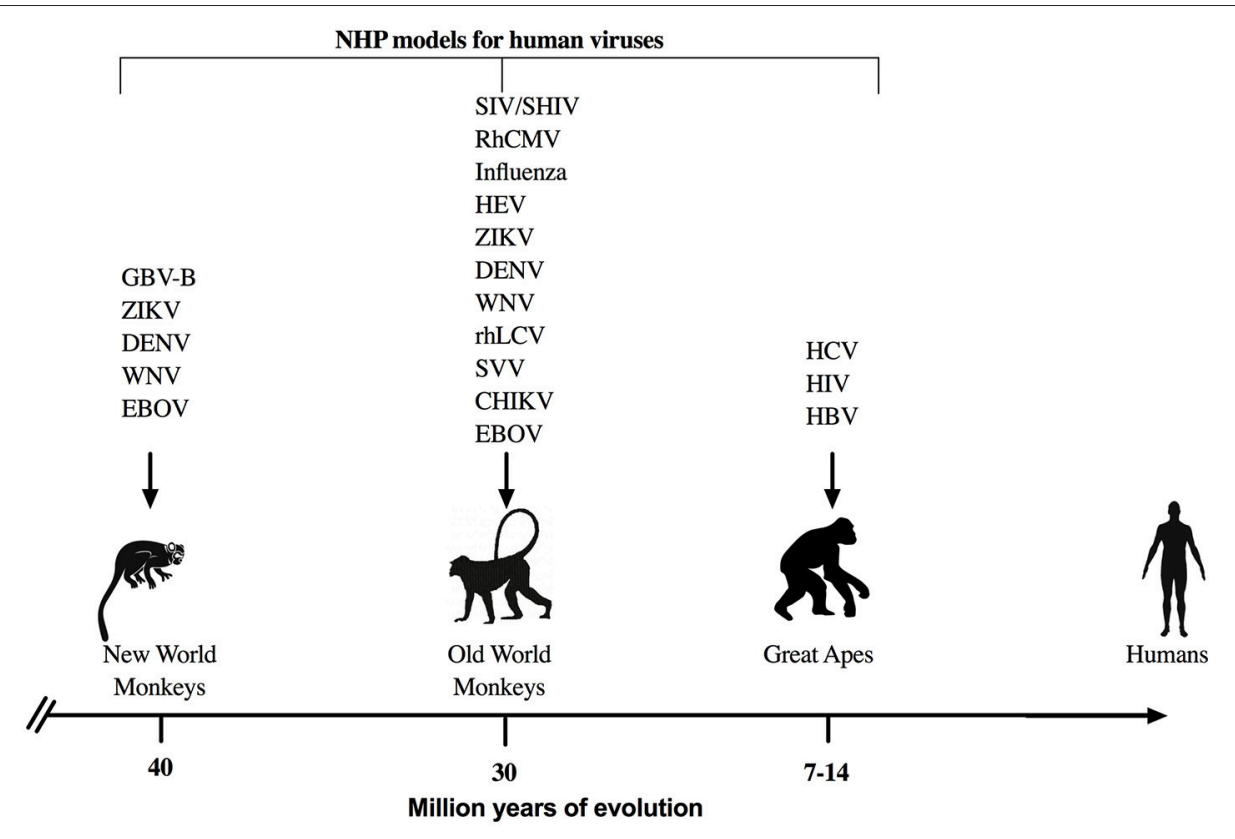

FIGURE 1 | NHP models for viral infections. Representation of NHP models that are used commonly to study human viral infections with respect to the evolutionary divergence from humans. GBV-B, GB virus-B; ZIKV, Zika virus; DENV, Dengue virus; WNV, West Nile virus; EBOV, Ebola virus; SIV, Simian Immunodeficiency virus; SHIV, Simian/Human Immunodeficiency virus; RhCMV, rhesus cytomegalovirus; HEV, Hepatitis E virus; rhLCV, rhesus lymphocryptovirus; SW, simian varicella virus; $\mathrm{CHIK}$, chikungunya virus, HIV, Human Imunodeficiency virus; HCV, Hepatitis C virus; and HBV, Hepatitis B virus are some of the most common examples for viral studies in NHP.

\section{Old World Monkeys}

The Old World monkeys are primarily found in the continents of Africa, Asia, and Europe with rhesus macaques (Macaca mulatta), cynomolgus macaques (Macaca fascicularis), sooty mangabeys (Cercocebus atys), African green monkeys (Chlorocebus aethiops), and baboons (Papio spp.) being the predominant species used in biomedical research. Rhesus/cynomolgus macaques are perhaps the most widely utilized NHP animal models to study human infectious diseases. Besides HIV (33), macaque models have been used for infectious diseases such as influenza $(34,35), \operatorname{HBV}(36,37), \operatorname{HCV}(38-40)$, measles (Morbillivirus) (41-43), cytomegalovirus (CMV) (4446), among many others (47). Sooty mangabeys and African green monkeys are also used to study HIV and African green monkeys are used as a model for influenza (48). Less commonly used tree shrews (Tupaia belangeri) have also been explored as a model for HCV infection $(49,50)$.

\section{New World Monkeys}

New World monkeys or neotropical primates include cottontop tamarins (Saguinus Oedipus), common marmosets (Callithrix jacchus), owl monkeys (Aotus lemurimus), and squirrel monkeys (Saimiri boliviensis), which are commonly located in Central and South America. Although, the New World monkeys are more divergent than Old World NHP from humans, they provide a distinct advantage in biomedical research due to their relatively smaller size and lower cost compared to other NHP. Marmosets and tamarins have been used to study many flaviviruses such as
HCV, Dengue, and Zika (51-56). Owl monkeys can be infected with Hepatitis E Virus (57) and at least some individual animals might have HIV-1 compatible CD4 alleles (58) making them potentially useful for HIV research. Squirrel monkeys have been utilized as animal models for HTLV-1 pathogenesis and vaccine development $(59,60)$ and as an experimental model for Nipah Virus (61).

\section{CYTOKINE DYSREGULATION IN VIRAL INFECTION MODELS}

\section{HIV/Acquired Immunodeficiency Syndrome (AIDS)}

The emergence of HIV (Genus: Lentivirus, Family: Retroviridae) is the result of the combination of at least four simian immunodeficiency virus (SIV) transmission events from chimpanzees or gorillas to humans $(62,63)$. Therefore, SIV and simian/human immunodeficiency virus (SHIV) infections in NHP are commonly used to model HIV pathogenesis and development of vaccines and therapeutics. Specifically, rhesus macaques and sooty mangabeys have been critical in understanding the early phase of the infection $(33,64)$. Several studies (discussed below) have shown the principal involvement of an unusually vigorous immune activation leading to the progression and establishment of AIDS.

Based on plasma parameters from HIV-infected patients, the virus-mediated cytokine storm starts early in infection even before peak viremia is reached $(65,66)$. It rapidly initiates a 
cascade of events characterized by the production of the early pro-inflammatory cytokines, IL-15, and IFN- $\alpha$, quickly followed by the more sustained TNF- $\alpha$ and monocyte chemoattractant protein (MCP)-1 during infection. Other pro-inflammatory cytokines like IL-6, IL-8, IL-18, and IFN- $\gamma$ are elevated 2 days post the first wave of proinflammatory cytokines. At the same time, the secretion of IL-10, an immunoregulatory cytokine exponentially increases until it peaks at 5 days of infection (65). While, the IL-10/IL10-R pathway has a major role in preventing tissue damage observed during HIV infection by inhibiting Th1 responses and the production of anti-viral cytokines (IFN- $\alpha$, IFN- $\gamma$, IL-2), it also contributes to viral persistence. Furthermore, the expression of the PD-1/PDL-1 pathway drives the inhibition of $\mathrm{T}$ cell function (67) and indirectly up-regulates expression of IL-10 (68). Indeed, blockade of PD-1 by anti-PD-1 antibody in infected rhesus macaques augmented SIV specific IFN- $\gamma$ responses in $\mathrm{CD} 8+\mathrm{T}$ cells in the blood, and could be synergized with vaccination and anti-retroviral therapies $(69,70)$. However, more NHP studies are necessary to establish the importance of PD-1 blockade particularly in mucosal tissues.

The magnitude of the cytokine storm is broadly associated with the clinical outcome in infected rhesus macaques and sooty mangabeys $(66,71)$. Indeed, the progressive infection in rhesus macaques is associated with production of IL-15, IL-18, IFN- $\gamma$, granulocyte-colony stimulating factor (G-CSF), MCP-1 and macrophage inflammatory protein (MIP)- $1 \beta$ but not in nonprogressive sooty mangabeys (66). Similar cytokine dysregulation evidenced as elevated IL-12 has also been reported in HIV seroconverts (72) and South African women who are high risk population for acquisition of HIV infection (73). Furthermore, the cytokine storm leads to immune activation with global damage in mucosal tissues, specifically the gut and gut-associated lymphoid tissue (GALT) which are the early and major sites of virus replication (74). Specifically, the virus targets the IL-17/Th17 pathway that is essential for preservation of the gut barrier, maintenance of the gut microbial environment, and prevention of translocation of microbial products into the circulation that could otherwise cause immune activation $(75,76)$. However, it is shown that cART can partially restore effective CD4+ T cells (more than 50\% compared to non-treated) in the gut and enhance the Th17 subset which is associated with a better clinical outcome (77). This further illustrates the importance of NHP to study gut immunity in HIV infection and evaluate therapeutic modalities at mucosal tissues (78).

SIV infection in sooty mangabeys leads to a long nonprogressive infection as observed in some HIV-infected individuals (79). Sooty mangabeys do not develop disease symptoms due to a low level of immune activation despite high level of viral replication (80). Instead of an inflammatory immune response, elevated regulatory $\mathrm{T}$ cells (Treg) and associated cytokines, TGF- $\beta$ and IL-10 limit the level of immune activation (80). Similarly in infected African green monkeys, an anti-inflammatory environment is rapidly established due to increases in Treg frequency, TGF- $\beta$, and IL-10 levels in the plasma (81). Interestingly, a comparison of acute infection in African green monkeys and rhesus macaques revealed that a rapid and elevated IFN- $\alpha$ is triggered in both models but return to baseline levels after 28 days of infection was observed only in African green monkeys (82). Further, no changes in the levels of pro-inflammatory cytokines such as IL-6, IL-18, and TNF- $\alpha$ were reported in infected African green monkeys compared to uninfected controls (83). It was also shown that sooty mangabeys have a unique genome that protects them from developing AIDS (84). Of importance, these animals possess a different TLR-4 gene compared to NHP that develop AIDS. TLR-4 is a pattern recognition receptor that senses lipopolysaccharides on bacteria and initiates pro-inflammatory cytokine induction. HIV can induce microbial translocation that elicited exacerbated TLR-4 stimulation and lead to chronic immune activation $(85,86)$. Therefore the differential cytokine response and an overall lower immune activation, in part confers immune protection, less tissue damage and maintenance of gut barrier in non-pathogenic SIV infection of sooty mangabeys as well as African green monkeys $(87,88)$.

Rhesus macaques are not natural hosts of SIV infection and therefore, some SIV strains can induce strong viral load and the development of AIDS similar to HIV-infected individual (89). In a rhesus macaque cohort infected with pathogenic or nonpathogenic strains of SIV/SHIV, the progressor cohort exhibited low IFN- $\gamma$ induced by CD4+ T cells compared to CD8 $+\mathrm{T}$ cells whereas, the non-progressor monkeys did not develop a similar immunomodulation (90). Furthermore, infection with virulent SIVmac251 strain directly upregulated the cytokine production (IFN- $\alpha / \beta$, IL-12, IL-18) and led to the activation of natural killer (NK) cells which are one of the major antiviral innate immune cells and also act as a bridge to the adaptive system. Interestingly, the production of antiviral cytokines (IFN- $\alpha$, IFN- $\gamma$, IL-2) was also associated with viral establishment (91). An over production of IL-7 in the gut during the early days of acute SIV infection in rhesus macaques could contribute to the cytokine storm by inducing elevated chemokine expression triggering immune cell recruitment (92). Overall, the cytokine storm induces a vicious cycle by spreading the infection and causing tissue damage due to an extensive inflammation in SIV progressive NHP models. To overcome this cytokine mediated disease exacerbation, several therapeutic formulations that use cytokines including IL-12, IL-15, and IL-2 or block cytokine receptors are increasingly being tested in SIV infection models (discussed in later section).

\section{Hepatitis B and C}

Hepatitis B and C infections together are the leading causes of chronic liver disease worldwide (93). HBV (Genus: Orthohepadnavirus; Family: Hepadnaviridae) and HCV (Genus: Hepacivirus; Family: Flaviviridae) are hepatotropic viruses and cause both acute and chronic liver infections, which can progress to fibrosis and hepatocellular carcinoma. Interestingly, both viruses have a narrow host range (humans and chimpanzees) and have similar pathogenesis for progressive liver damage and persistence of infection. Studies in chimpanzees showed that HBV and HCV are not directly cytopathic (94-97) but instead cause liver injury due to chronic immune activation. Adaptive T cell and NK cell immunity are important in the control of viral hepatitis, but they can also prove detrimental in persistent infection. In cases of uncontrolled replication, infected 
hepatocytes secrete cytokines IL-8, CXCL-9, and CXCL-10, which recruit $\mathrm{T}$ cells to the infected liver, all correlating with histological damage (98-100). Further, innate immune NK cells are activated and recruited by high levels of IFN- $\alpha$ and IL-8 in the liver and induction of cytotoxic TRAIL pathway leads to killing of hepatocytes and liver injury (101). HCVmediated liver inflammation is promoted by IL- $1 \beta$ and the TNF superfamily cytokines such as TNF- $\alpha$, TNF- $\beta$, TWEAK, and LIGHT through the activation of NF-kB and MLCK-signaling pathways to reduce hepatocellular tight junction integrity (102, 103). In HBV infection, TNF- $\alpha$ secretion was associated with significant fibrosis, and IL-10 and IFN- $\gamma$ were associated with necroinflammation (104). Additionally, as a result of viral overload, induction of interferon stimulated genes and elevated IL-8 and chemokines such as CCL2, CXCL1, and CXCL5 results in cholestatic $\mathrm{HCV}$, which is associated with metabolic dysregulation $(105,106)$.

Due to the narrow host range, chimpanzees were critical for initially understanding the natural history and pathogenesis of HCV and HBV $(32,107)$. However, because of the limited use of chimpanzees currently, other surrogate animal models are being employed. To model HBV, cynomolgus macaques have been used but with an indirect infection approach: ex-vivo baculovirusmediated HBV genome transfer in hepatocytes to cross the species barrier (108). Recently, a new virus called the capuchin monkey hepatitis $\mathrm{B}$ virus (CMHBV) has been discovered in Brazilian capuchin monkeys, a neotropical primate and has potential implications in the development of the much needed animals model for hepatitis B (109). The more commonly used NHP models for HCV are infections of neotropical primates, marmosets and tamarins, with the surrogate hepacivirus GBVB of the same family Flaviviridae $(51,110,111)$. Several studies showed that activated $\mathrm{T}$ cell immune responses and IFN- $\gamma$ secretion are important for clearance of GBV-B $(112,113)$. However, similar to $\mathrm{HCV}$-infected liver, immune activation correlated with liver damage in primary infections and reinfections in marmosets $(114,115)$. Activated NK cells expressing IFN- $\gamma$ and perforin were accumulated in the liver and in addition elevated plasma IFN- $\gamma$ and RANTES were associated with acute hepatitis in infected animals (114). Further, infected marmosets developed metabolic dysfunctions associated with GBV-B infection even after clearance of viremia indicating that viral hepatitis induces a cascade of events toward hepatic and systemic inflammation. Particularly, imbalance in levels of proinflammatory adipocytokines such as resistin and plasminogen activator inhibitor-1 secreted by dysfunctional adipose tissues contribute to local, systemic, and metabolic malfunctions (116). Given the importance of liver immune responses in progression of viral hepatitis, limited access to liver tissues has severely impeded development of HCV vaccine and HBV therapeutics.

\section{Zika}

Infections with Zika virus (ZIKV; Genus: Flavivirus; Family: Flaviviridae) have recently caused a pandemic due to abortions, stillbirths, congenital birth defects, and neonate deaths called the congenital Zika syndrome (CZS) (117). ZIKV induced neuronal necrosis in the cortical layer of the brain is mediated by a complex array of cytokines and immune factors (118-120). While studies in brain tissue are limited, in-situ immunostaining of infected fetal brain samples showed that the predominant immune response was characterized by IL-4, IL-10, IL-33, iNOS, and arginase and therefore was generally skewed toward a Th2 response (118). IL-33, in particular is directly involved in pyroptosis, activation of inflammasomes, endoplasmic reticulum stress potentially leading to cellular damage (119). However, other cytokine responses indicative of Th1, Th17, Treg, Th9, and Th22 response were also involved to a lesser extent. Immune cells including microglia, CD4+ and CD8 + T cells, Treg, NK cells, M1/ M2 macrophages, and antigen-presenting cells contribute to the pathogenesis of the ZIKV induced inflammation (118). Thus, a complex relationship between different immune factors, cell damage, and direct viral action leads to ZIKV meningitis and encephalitis.

While ZIKV induced pathology and pathogenesis studies in humans are limited to samples obtained from autopsy of severe fatal cases, NHP have been tremendously helpful in elucidating pathogenesis and fast tracked development of several vaccine candidates (121-123). Indeed, fetal neuropathology, microcephaly, and other CZS symptoms were evidenced in several NHP models including rhesus, pigtail, and cynomolgus macaques, common marmosets, and squirrel monkeys infected during early pregnancy $(55,56,124-128)$. Infection studies in common marmoset dams identified immune pathways in maternal viral responses. Interestingly, an increase in IFN$\gamma$ and pro-inflammatory cytokines as early as day 2 postinfection was reported. The pro-inflammatory response was maintained as elevated induction of type I/II IFN associated genes and pro-inflammatory cytokines even at day 7 postinfection and spontaneous abortion after 16-18 days of infection was reported with extensive viral infection in placenta and fetal tissues $(56,125)$. In infected rhesus macaques, viral persistence in the central nervous system and lymph nodes correlated with robust and early induction of proinflammatory responses and mTOR signaling pathways as evidenced by IFN- $\alpha$ induction at day 2, 4, and 6 postinfection and upregulation of transcript components of IFN$\alpha$ and IFN-stimulated genes (ISGs) (OAS2, IFT1/2/3, ISG15, IRF7, IFI44, MX1, and MX2), pro-inflammatory cytokines and chemokines (TNF- $\alpha$, IL-1, IL18, CCR7, CCL2, and CCL20), immunomodulatory pathways (IL-10, TGF- $\beta$, and T regulatory cells), and inflammasome pathways (NOD2, NLRP3, CXCL10, BTG2, BST2, OSM) at day 6 post-infection (129). As a result of these activated pathways, ZIKV persistence could contribute to the characteristic neuropathology associated with ZIKV. Further several experiments in NHP are currently underway for preclinical testing of vaccine candidates and Zika is an excellent example to illustrate the importance of NHP in developing vaccines within a short span of time.

\section{Dengue}

Dengue virus (DENV; Genus: Flavivirus; Family: Flavivirdae), is a major vector borne disease in tropical and subtropical countries affecting approximately 100 million people worldwide, which can progress from the typical Dengue fever to fatal conditions such as 
Dengue hemorrhagic fever (DHF) and Dengue shock syndrome (DSS). Damage to vascular endothelium and uncontrolled activation of blood coagulation pathways in DHF can result in critical hypovolemic shock in DSS. Increased levels of cytokines, such as IFNs, IL-2, IL-8, TNF- $\alpha$, and vascular endothelial growth factor A (VEGF-A) have all been reported to be associated with vascular leakage (130). Increased $\mathrm{T}$ cell activation and cytokine production in patients during both primary and secondary Dengue virus infections showed greater clinical severity of illness associated with cytokine storm characterized by elevated plasma pro-inflammatory cytokines such as IFN- $\gamma$, IL-6, IL-8, IL-10, CXCL9, CXCL10, CXCL11, MIF, TNF- $\alpha$, and VEGF $(130,131)$.

Several NHP species are permissive to Dengue infection including chimpanzees, rhesus and cynomolgus macaques, sooty mangabeys, common marmosets, and owl monkeys, however the DENV induced hemorrhagic disease pattern is less common in NHP [reviewed in (132)]. In addition to elevated TGF- $\alpha$ and IFN- $\gamma$, increases in MCP-1, which drives immune cell recruitment, and potential cause of vascular damage was found elevated in rhesus macaques infected with DENV (133). A high dose intravenous inoculation of DENV induced classic dengue hemorrhage in infected rhesus macaques 3-5 days post-infection, with altered serum biochemical parameters indicative of coagulopathy (134). Similarly cytokine storm associated with enhanced dengue disease was detected in DENV infected marmosets, which showed a significant increase in plasma TNF- $\alpha$ as early as 3 days post-infection and significantly increased IFN- $\gamma$ at 3,6 , and 20 days post-infection $(52,135)$. Indeed, antibody enhanced dengue disease in marmosets lead to CNS injury and was associated with intense TNF- $\alpha$ immunostaining in brain samples (135). Further, based on biomarker network analysis, two relevant strong axes during early stages of dengue fever were identified-a protective axis composed of TNF- $\alpha /$ lymphocytes/platelets, and a pathological axis IL-2/IL-6/monocyte/prothrombin time/viremia. Later time points post-infection showed the interaction of IFN$\gamma /$ platelets/DENV-3/prothrombin time, and the involvement of type- 2 cytokines (IL-4, IL-5) (136). Overall, these studies indicate that elevated proinflammatory cytokines in dengue-infected NHP have a pathogenic role associated with disease severity.

\section{Influenza}

Influenza A virus (Genus: Influenzavirus A; Family: Orthomyxoviridae) causes acute and severe respiratory illness in more than 1 billion people worldwide. The severity of influenza infection derives from the interplay between the virus and the host's ability to control viral infection and spread. In severe cases the host's response is hyperactivated and the resulting inflammatory response produces a cytokine storm (137-139) that is responsible for tissue injury and potentially death. This was seen during the $1918 \mathrm{H} 1 \mathrm{~N} 1$ pandemic and more recently via the spread of H5N1. Endothelial cells from the lung have been implicated as key players in propagating the cytokine storm, in part from having elevated levels of CCL2, CCL5, and CXCL10 (140). Further inhibiting S1P1 receptor signaling on pulmonary endothelial cells, which leads to downregulation of cytokine/chemokine signaling, has been shown to decrease the development of cytokine storm following infection with influenza $(140,141)$.

One of the major issues in NHP modeling of influenza is the result of low animal mortality as compared to what happens in humans. While NHP can be infected with seasonal influenza strains they do not always display symptoms akin to those seen in humans (142). Influenza infection in NHP may lead to a biphasic subclinical fever early during the infection (143, 144), but this seems to be dependent on the mode of infection and dosage utilized $(145,146)$. Aerosol delivery using the full head chamber (145) results in a more lethal outcome, whereas the facemask leads to less severe symptoms. Infection with highly pathogenic influenza strains can induce clinical symptoms such as fever, cough and lethargy, and even showing signs of acute respiratory distress syndrome (124), bronchointerstitial pneumonia, peribronchiolar alveolitis, edema, and hemorrhaging (147-150). Further, in this model and others, increased levels of IP-10 (CXCL10), MCP-1 (CCL2), and IL-6 have been observed, which have been characterized as hallmarks of H5N1 human infection $(138,139,151-153)$. Gene expression analyses have also shown that CXCL10 and CXCL11 are highly upregulated early during infection with highly pathogenic H1N1 and H5N1 and associated with elevated tissue damage $(151,152,154)$. Using the full head chamber allows for the macaques to develop fulminant pneumonia that rapidly progressed to acute respiratory distress syndrome, which is the result of widespread alveolar epithelial cell death as well as depletion of alveolar macrophages.

\section{CMV}

CMV (Genus: Cytomegalovirus; Family: Herpesviridae) can infect and persist lifelong in multiple cell types such as macrophages, neutrophils, fibroblasts, neuronal cells, hepatocytes and others (155-159). Human CMV (HCMV) infections are often reported in patients with suppressed immune system, including the elderly, AIDS patients, cancer patients, and transplant recipients. After infection, CMV hijacks cellular machinery, induces significant alterations in gene expression including IFN signaling genes, followed by a complex cascade of signaling events $(160,161)$ leading to upregulation of transcription factors like NF- $\mathrm{B}$ and altered cytokine production, and thus successfully evades the host immune surveillance and disseminates to all organs (162-167). While the pathogenesis is not completely clear, elevated levels of MCP-1 and MIP- $1 \alpha$ recruiting monocyte and macrophages to the site of infection could mediate tissue damage with uncontrolled viral replication in immunocompetent patients $(168,169)$. In congenital CMV infections, which cause severe birth defects in newborn babies, elevated MCP-1 and TNF- $\alpha$ in placenta could lead to adverse pregnancy outcomes or even death in utero $(170,171)$. Another group reported severe CNS abnormalities and brain vasculature damage in newborn babies due to proinflammatory cytokines IL- 8 , IL- 6 , TNF- $\alpha$, and IL- $1 \beta$ upregulated by CMV infection of pericytes (172).

HCMV does not infect animals due to the species specificity of beta herpesviruses and interestingly the virus has co-evolved with its host species (173). Therefore, the study of specific $\mathrm{CMV}$ in their respective species of animal models has been 
helpful in elucidating CMV specific immunity. Indeed, simian CMV seroprevalence was reported in baboons, African green monkeys, and rhesus macaques as early as 1971 (174) and currently, rhesus CMV (RhCMV) infections in rhesus macaques is more commonly used as a NHP model (175). Since the global prevalence of HCMV ranges from 60 to 100\%, animal models offer a unique advantage of being specific pathogen free, in this case CMV-free, in order to understand CMV immunity in comparison to uninfected population. RhCMV is particularly useful to model congenital infections (176) and co-infections such as CMV and HIV infections in the same host (177). Intrauterine inoculation of pregnant dams and intraamniotic/intracranial inoculations of the fetuses with RhCMV led to severe neurological defects and CNS lesion similar to HCMV (45, 176, 178). Further, RhCMV studies helped identify that the primate CMV encodes and expresses IL-10 homolog genes in vivo (179). Interestingly, the viral homolog had evolved functions that are beneficial to viral replication, primarily through immunosuppressive and antiproliferative effects on host immune cells (179). The CMV IL-10 could also play a role in CMV's ability to subvert NK cell reactivity, thus avoiding NK cell lysis (179). Further, exploration of RhCMV infections in CMV free animals can identify immunopathogenesis pathways and therapeutic targets.

\section{IMMUNOTHERAPEUTIC APPROACHES}

Recombinant cytokines and anti-cytokine antibodies have recently gained traction in the pharmaceutical arena as a novel class of drugs for therapeutic purposes especially in autoimmune disorders and cancer $(180,181)$. There are few cytokine therapies that are already in use for therapy against viral infections such as IFN- $\alpha$ for HBV and HCV therapy. To overcome the severe side effects of IFN- $\alpha$ therapy, recently type III IFNs namely IFN- $\lambda$ which have similar biological functions as IFN- $\alpha$, have been tested preclinically in rhesus macaques (182). IFN- $\lambda$ demonstrated antiviral effects similar to IFN- $\alpha$ without hematologic toxicity and thus could be used as an alternative therapy in chronic hepatitis patients. IL-12 administration has been previously studied in chimpanzees and rhesus macaques for understanding IL-12 mediated pathways and antiviral protection in SIV infections respectively $(183,184)$. IL-15 agonist, which has immunomodulatory functions, activates innate and adaptive immunity, and has been well characterized in NHP (185-188). Recently, a novel IL-15 superagonist ALT 803 potentiated T cell and NK cell responses leading to transient viral suppression in ART naïve SIV infected rhesus macaques (189). While the viral suppression was transient, this study illustrates IL-15 as a potential therapeutic agent particularly in combination therapy and ALT 803 is already in clinical trials for cancer therapy (190, 191). Even in DNA vaccine studies, IL-2 administration augmented vaccine elicited HIV-1, and SIV-1 specific immune responses in SHIV challenged rhesus macaques (192) thus showing that cytokine co-administrations can potentiate both vaccines and therapeutics.

Blocking of cytokine receptors or administration of cytokine antagonists can also be helpful in control of viral replication. Antagonists of CCR5 (maraviroc and vicriviroc) and CXCR4 inhibitor (Plerixafor) are relevant as they block HIV entry in cells and therefore can be used for HIV treatment (193). In addition to these small molecule CCR5 inhibitors, CCR5 blocking antibodies have also been characterized in preclinical rhesus macaques model of SIV infection (194-196). Further, maraviroc prevented cardiac dysfunction and cardiomyopathy associated with AIDS by blocking CCL5 and its recruitment of inflammatory macrophages in the heart tissue of SIV infected rhesus macaques (197).

Cytokine-based therapeutics are increasingly tested for other non-viral disease models of NHP. IL-13 neutralization for prevention of $\operatorname{IgE}$ mediated allergic responses in airway inflammation model of cynomolgus macaques (198), IL-6 receptor blocking and anti-TNF agent, infliximab for treatment of rheumatoid arthritis in cynomolgus macaques and rhesus macaques, IFN- $\alpha$ treatment effects in rhesus macaques model of cytokine induced depression $(199,200)$ are some of the few examples and could have potential applications in viral immunity and therapy. While cytokine therapy is advantageous in controlling viral replication or preventing tissue damage, systemic administration of cytokine, or cytokine blocking can result in altered hematopoiesis and immune activation, and

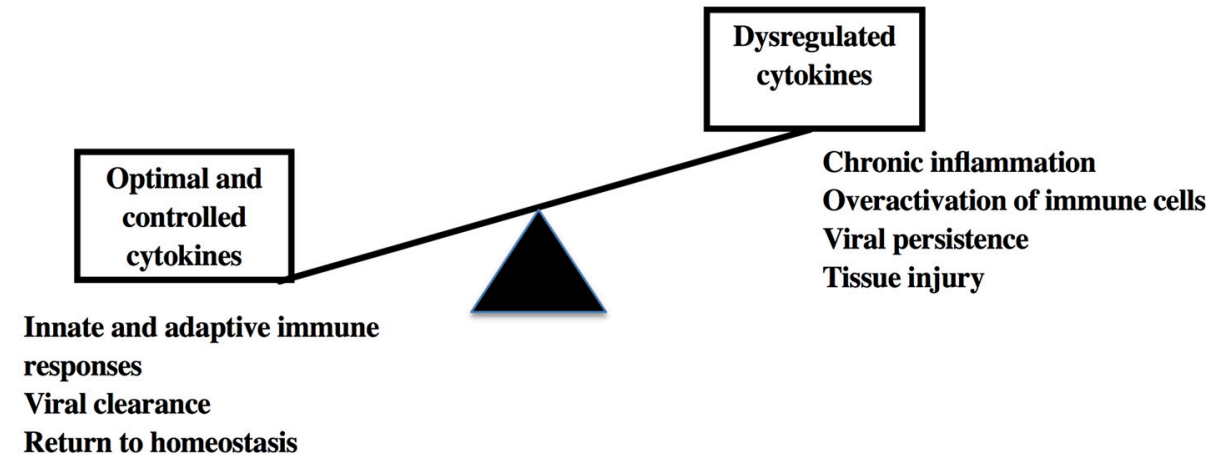

FIGURE 2 | Cytokine responses and sequelae in viral infections. 
severe complications due to the pleiotropic nature of cytokines in long-term therapy. Even in co-inhibitor receptors/checkpoint blockade therapy such as anti-PD-1 or CTLA-4 therapy commonly used for reversion of exhausted $\mathrm{T}$ cells in cancer and chronic diseases, undue immune activation or autoimmune responses is a primary risk leading to systemic or organ toxicities associated with uncontrolled inflammatory cytokine secretion and cytotoxicity by activated immune cells, which in turn require additional or follow-up immunosuppressive treatment [reviewed in $(201,202)]$. Therefore, development of site directed biologics or cytokine therapy targeting viral infected tissues would be more beneficial than systemic administration.

\section{CONCLUSION}

Within the last few years, cytokines have been identified as key diagnostic, prognostic, and therapeutic agents in human diseases. Their multifaceted roles in immunity, tissue protection, and remodeling, maintenance of systemic and metabolic homeostasis make them important biomarkers for understanding and treating infectious diseases, cancer, auto-immune diseases, metabolic dysfunctions and other inflammatory processes.

\section{REFERENCES}

1. Vossen MT, Westerhout EM, Soderberg-Naucler C, Wiertz EJ. Viral immune evasion: a masterpiece of evolution. Immunogenetics (2002) 54:527-42. doi: 10.1007/s00251-002-0493-1

2. Sirskyj D, Theze J, Kumar A, Kryworuchko M. Disruption of the gamma c cytokine network in T cells during HIV infection. Cytokine (2008) 43:1-14. doi: 10.1016/j.cyto.2008.03.001

3. Bixler SL, Goff AJ. The role of cytokines and chemokines in filovirus infection. Viruses (2015) 7:5489-507. doi: 10.3390/v7102892

4. Beltra JC, Decaluwe H. Cytokines and persistent viral infections. Cytokine (2016) 82:4-15. doi: 10.1016/j.cyto.2016.02.006

5. Becher B, Spath S, Goverman J. Cytokine networks in neuroinflammation. Nat Rev Immunol. (2017) 17:49-59. doi: 10.1038/nri.2016.123

6. Isaacs A, Lindenmann J. Virus interference. I The interferon. Proc R Soc Lond B Biol Sci. (1957) 147:258-67. doi: 10.1098/rspb.1957.0048

7. Hoofnagle JH, Mullen KD, Jones DB, Rustgi V, Di Bisceglie A, Peters M, et al. Treatment of chronic non-A,non-B hepatitis with recombinant human alpha interferon. A preliminary report $N$ Engl J Med. (1986) 315:1575-8. doi: 10.1056/NEJM198612183152503

8. Dusheiko G. Side effects of alpha interferon in chronic hepatitis C. Hepatology (1997) 26:112S-121S. doi: 10.1002/hep.510260720

9. Bukowski, R. M., Olencki, T., Mclain, D., and Finke, J. H. (1994). Pleiotropic effects of cytokines: clinical and preclinical studies. Stem Cells 12(Suppl 1):129-40; discussion: 140-21.

10. Martin R. Interleukin 4 treatment of psoriasis: are pleiotropic cytokines suitable therapies for autoimmune diseases? Trends Pharmacol Sci. (2003) 24:613-6. doi: 10.1016/j.tips.2003.10.006

11. Liao W, Lin JX, Leonard WJ. IL-2 family cytokines: new insights into the complex roles of IL-2 as a broad regulator of T helper cell differentiation. Curr Opin Immunol. (2011) 23:598-604. doi: 10.1016/j.coi.2011. 08.003

12. Xu L, Tian D, Zheng Y. Pleiotropic roles of TGFbeta/Smad signaling in the progression of chronic liver disease. Crit Rev Eukaryot Gene Expr. (2013) 23:237-55. doi: 10.1615/CritRevEukaryotGeneExpr.2013007490

13. Iwasaki Y, Fujio K, Okamura T, Yamamoto K. Interleukin-27 in T cell immunity. Int J Mol Sci. (2015) 16:2851-63. doi: 10.3390/ijms16022851
However, it is very important that their use in conjunction with other therapeutic and preventative strategies needs to be tested in pre-clinical models due to their propensity to cause immunopathology and tissue injury leading to serious complications in certain conditions (Figure 2). The usage of NHP models will be helpful for early prevention of tissue injury and associated autoimmune and metabolic syndromes that arise in diseases caused by viral and non-viral causes.

\section{AUTHOR CONTRIBUTIONS}

CM and SVS performed most of the writing. OL and DRR contributed to writing of specific sections. RKR oversaw overall preparation of the manuscript, contributed to writing, and edited the final version of the manuscript.

\section{FUNDING}

This work was supported by National Institutes of Health (NIH) grants R01 DE026327, R01 DE026014, and R01 AI120828 to RKR. DRR was supported, in part, by T32 AI007387. The funders had no role in study design, data collection and analysis, decision to publish, or preparation of the manuscript.

14. Yao X, Sun Y, Wang W, Sun Y. Interleukin (IL)-25: pleiotropic roles in asthma. Respirology (2016) 21:638-47. doi: 10.1111/resp.12707

15. Ericsson AC, Crim MJ, Franklin CL. A brief history of animal modeling. Mo Med. (2013) 110:201-5.

16. Seok J, Warren HS, Cuenca AG, Mindrinos MN, Baker HV, Xu W, et al. Genomic responses in mouse models poorly mimic human inflammatory diseases. Proc Natl Acad Sci USA. (2013) 110:3507-12. doi: $10.1073 /$ pnas. 1222878110

17. Du Y, Deng W, Wang Z, Ning M, Zhang W, Zhou Y, et al. Differential subnetwork of chemokines/cytokines in human, mouse, and rat brain cells after oxygen-glucose deprivation. J Cereb Blood Flow Metab. (2017) 37:142534. doi: 10.1177/0271678X16656199

18. Punnonen J, Aversa G, Cocks BG, Mckenzie AN, Menon S, Zurawski G, et al. Interleukin 13 induces interleukin 4-independent IgG4 and IgE synthesis and CD23 expression by human B cells. Proc Natl Acad Sci USA. (1993) 90:3730-4. doi: 10.1073/pnas.90.8.3730

19. Zurawski G, De Vries JE. Interleukin 13, an interleukin 4-like cytokine that acts on monocytes and B cells, but not on T cells. Immunol Today (1994) 15:19-26. doi: 10.1016/0167-5699(94)90021-3

20. Peschon JJ, Morrissey PJ, Grabstein KH, Ramsdell FJ, Maraskovsky E, Gliniak BC, et al. Early lymphocyte expansion is severely impaired in interleukin 7 receptor-deficient mice. J Exp Med. (1994) 180:1955-60. doi: 10.1084/jem.180.5.1955

21. Roifman CM, Zhang J, Chitayat D, Sharfe N. A partial deficiency of interleukin-7R alpha is sufficient to abrogate T-cell development and cause severe combined immunodeficiency. Blood (2000) 96:2803-7.

22. Coers J, Starnbach MN, Howard JC. Modeling infectious disease in mice: coadaptation and the role of host-specific IFNgamma responses. PLoS Pathog. (2009) 5:e1000333. doi: 10.1371/journal.ppat.1000333

23. Carlsson HE, Schapiro SJ, Farah I, Hau J. Use of primates in research: a global overview. Am J Primatol. (2004) 63:225-37. doi: 10.1002/ajp. 20054

24. Friedman H, Ator N, Haigwood N, Newsome W, Allan JS, Golos TG, et al. The critical role of nonhuman primates in medical research. Pathog Immun. (2017) 2:352-65. doi: 10.20411/pai.v2i3.186

25. Hoglind A, Arestrom I, Ehrnfelt C, Masjedi K, Zuber B, Giavedoni L, et al. Systematic evaluation of monoclonal antibodies and immunoassays 
for the detection of Interferon-gamma and Interleukin-2 in old and new world non-human primates. J Immunol. Methods (2017) 441:39-48. doi: 10.1016/j.jim.2016.11.011

26. Makitalo B, Andersson M, Arestrom I, Karlen K, Villinger F, Ansari A, et al. ELISpot and ELISA analysis of spontaneous, mitogen-induced and antigenspecific cytokine production in cynomolgus and rhesus macaques. J Immunol Methods (2002) 270:85-97. doi: 10.1016/S0022-1759(02)00274-0

27. Giavedoni LD. Simultaneous detection of multiple cytokines and chemokines from nonhuman primates using luminex technology. $J$ Immunol Methods (2005) 301:89-101. doi: 10.1016/j.jim.2005.03.015

28. Riccio EK, Pratt-Riccio LR, Bianco-Junior C, Sanchez V, Totino PR, Carvalho $\mathrm{LJ}$, et al. Molecular and immunological tools for the evaluation of the cellular immune response in the neotropical monkey Saimiri sciureus, a non-human primate model for malaria research. Malar J. (2015) 14:166. doi: 10.1186/s12936-015-0688-1

29. Kalter SS. Nonhuman primates in viral research. Ann N Y Acad Sci. (1969) 162:499-528. doi: 10.1111/j.1749-6632.1969.tb56400.x

30. Abe K, Kurata T, Teramoto Y, Shiga J, Shikata T. Lack of susceptibility of various primates and woodchucks to hepatitis C virus. J Med Primatol. (1993) 22:433-4.

31. Eren R, Ilan E, Nussbaum O, Lubin I, Terkieltaub D, Arazi Y, et al. Preclinical evaluation of two human anti-hepatitis B virus (HBV) monoclonal antibodies in the HBV-trimera mouse model and in HBV chronic carrier chimpanzees. Hepatology (2000) 32:588-96. doi: 10.1053/jhep.2000.9632

32. Wieland SF. The chimpanzee model for hepatitis B virus infection. Cold Spring Harb Perspect Med. (2015) 5:a021469. doi: 10.1101/cshperspect.a021469

33. Letvin NL, Daniel MD, Sehgal PK, Desrosiers RC, Hunt RD, Waldron LM, et al. Induction of AIDS-like disease in macaque monkeys with T-cell tropic retrovirus STLV-III. Science (1985) 230:71-3. doi: 10.1126/science.2412295

34. Rimmelzwaan GF, Kuiken T, Van Amerongen G, Bestebroer TM, Fouchier RA, Osterhaus AD. Pathogenesis of influenza A (H5N1) virus infection in a primate model. J Virol. (2001) 75:6687-91. doi: 10.1128/JVI.75.14.6687-6691.2001

35. Baas T, Baskin CR, Diamond DL, Garcia-Sastre A, Bielefeldt-Ohmann $\mathrm{H}$, Tumpey TM, et al. Integrated molecular signature of disease: analysis of influenza virus-infected macaques through functional genomics and proteomics. J Virol. (2006) 80:10813-28. doi: 10.1128/JVI.00851-06

36. Barker LF, Maynard JE, Purcell RH, Hoofnagle JH, Berquist KR, London WT. Viral hepatitis, type B, in experimental animals. Am J Med Sci. (1975) 270:189-95. doi: 10.1097/00000441-197507000-00026

37. Zuckerman AJ, Scalise G, Mazaheri MR, Kremastinou J, Howard CR, Sorensen K. Transmission of hepatitis B to the rhesus monkey. Dev Biol Stand. (1975) 30:236-9.

38. Li Q, Dong C, Wang J, Che Y, Jiang L, Wang J, et al. Induction of hepatitis $\mathrm{C}$ virus-specific humoral and cellular immune responses in mice and rhesus by artificial multiple epitopes sequence. Viral Immunol. (2003) 16:321-33. doi: 10.1089/088282403322396127

39. Rollier C, Verschoor EJ, Paranhos-Baccala G, Drexhage JA, Verstrepen BE, Berland JL, et al. Modulation of vaccine-induced immune responses to hepatitis $\mathrm{C}$ virus in rhesus macaques by altering priming before adenovirus boosting. J Infect Dis. (2005) 192:920-9. doi: 10.1086/432517

40. Capone S, Meola A, Ercole BB, Vitelli A, Pezzanera M, Ruggeri L, et al. A novel adenovirus type 6 (Ad6)-based hepatitis C virus vector that overcomes preexisting anti-ad5 immunity and induces potent and broad cellular immune responses in rhesus macaques. J Virol. (2006) 80:1688-99. doi: 10.1128/JVI.80.4.1688-1699.2006

41. Albrecht P, Burnstein T, Klutch MJ, Hicks HT, Ennis FA. Subacute sclerosing panencephalitis: experimental infection in primates. Science (1977) 195:64-6. doi: 10.1126/science. 831255

42. Hicks JT, Sullivan JL, Albrecht P. Immune responses during measles infection in immunosuppressed rhesus monkeys. J Immunol. (1977) 119:1452-6.

43. Kobune F, Takahashi H, Terao K, Ohkawa T, Ami Y, Suzaki Y, et al. Nonhuman primate models of measles. Lab Anim Sci. (1996) 46:315-20.

44. Vogel P, Weigler BJ, Kerr H, Hendrickx AG, Barry PA. Seroepidemiologic studies of cytomegalovirus infection in a breeding population of rhesus macaques. Lab Anim Sci. (1994) 44:25-30.
45. Tarantal AF, Salamat MS, Britt WJ, Luciw PA, Hendrickx AG, Barry PA. Neuropathogenesis induced by rhesus cytomegalovirus in fetal rhesus monkeys (Macaca mulatta). J Infect Dis. (1998) 177:446-50. doi: $10.1086 / 514206$

46. Lockridge KM, Sequar G, Zhou SS, Yue Y, Mandell CP, Barry PA. Pathogenesis of experimental rhesus cytomegalovirus infection. J Virol. (1999) 73:9576-83.

47. Gardner MB, Luciw PA. Macaque models of human infectious disease. ILAR J. (2008) 49:220-55. doi: 10.1093/ilar.49.2.220

48. Dinapoli JM, Yang L, Suguitan AJr, Elankumaran S, Dorward DW, Murphy $\mathrm{BR}$, et al. Immunization of primates with a Newcastle disease virus-vectored vaccine via the respiratory tract induces a high titer of serum neutralizing antibodies against highly pathogenic avian influenza virus. J Virol. (2007) 81:11560-8. doi: 10.1128/JVI.00713-07

49. Xie ZC, Riezu-Boj JI, Lasarte JJ, Guillen J, Su JH, Civeira MP, et al. Transmission of hepatitis C virus infection to tree shrews. Virology (1998) 244:513-20. doi: 10.1006/viro.1998.9127

50. Zhao X, Tang ZY, Klumpp B, Wolff-Vorbeck G, Barth H, Levy S, et al. Primary hepatocytes of Tupaia belangeri as a potential model for hepatitis C virus infection. J Clin Invest. (2002) 109:221-32. doi: 10.1172/JCI0213011

51. Lanford RE, Chavez D, Notvall L, Brasky KM. Comparison of tamarins and marmosets as hosts for GBV-B infections and the effect of immunosuppression on duration of viremia. Virology (2003) 311:72-80. doi: 10.1016/S0042-6822(03)00193-4

52. Omatsu T, Moi ML, Hirayama T, Takasaki T, Nakamura S, Tajima S, et al. Common marmoset (Callithrix jacchus) as a primate model of dengue virus infection: development of high levels of viraemia and demonstration of protective immunity. J Gen Virol. (2011) 92:2272-80. doi: 10.1099/vir.0.031229-0

53. Yoshida T, Omatsu T, Saito A, Katakai Y, Iwasaki Y, Iijima S, et al. CD16(+) natural killer cells play a limited role against primary dengue virus infection in tamarins. Arch Virol. (2012) 157:363-8. doi: 10.1007/s00705-011-1178-6

54. Manickam C, Reeves RK. Modeling HCV disease in animals: virology, immunology and pathogenesis of HCV and GBV-B infections. Front Microbiol. (2014) 5:690. doi: 10.3389/fmicb.2014.00690

55. Chiu CY, Sanchez-San Martin C, Bouquet J, Li T, Yagi S, Tamhankar M, et al. Experimental Zika virus inoculation in a new world monkey model reproduces key features of the human infection. Sci Rep. (2017) 7:17126. doi: 10.1038/s41598-017-17067-w

56. Seferovic M, Martin CS, Tardif SD, Rutherford J, Castro ECC, Li T, et al. Experimental Zika virus infection in the pregnant common marmoset induces spontaneous fetal loss and neurodevelopmental abnormalities. Sci Rep. (2018) 8:6851. doi: 10.1038/s41598-018-25205-1

57. Ticehurst J, Rhodes LL Jr, Krawczynski K, Asher LV, Engler WF, Mensing TL, et al. Infection of owl monkeys (Aotus trivirgatus) and cynomolgus monkeys (Macaca fascicularis) with hepatitis E virus from Mexico. J Infect Dis. (1992) 165:835-45. doi: 10.1093/infdis/165.5.835

58. Meyerson NR, Sharma A, Wilkerson GK, Overbaugh J, Sawyer SL. Identification of Owl monkey CD4 receptors broadly compatible with earlystage HIV-1 isolates. J Virol. (2015) 89:8611-22. doi: 10.1128/JVI.00890-15

59. Kazanji M, Tartaglia J, Franchini G, De Thoisy B, Talarmin A, Contamin $\mathrm{H}$, et al. Immunogenicity and protective efficacy of recombinant human T-cell leukemia/lymphoma virus type 1 NYVAC and naked DNA vaccine candidates in squirrel monkeys (Saimiri sciureus). J Virol. (2001) 75:5939-48. doi: 10.1128/JVI.75.13.5939-5948.2001

60. Mortreux F, Kazanji M, Gabet AS, De Thoisy B, Wattel E. Two-step nature of human T-cell leukemia virus type 1 replication in experimentally infected squirrel monkeys (Saimiri sciureus). J Virol. (2001) 75:1083-9. doi: 10.1128/JVI.75.2.1083-1089.2001

61. Marianneau P, Guillaume V, Wong T, Badmanathan M, Looi RY, Murri S, et al. Experimental infection of squirrel monkeys with nipah virus. Emerg Infect Dis. (2010) 16:507-10. doi: 10.3201/eid1603.091346

62. Tebit DM, Arts EJ. Tracking a century of global expansion and evolution of HIV to drive understanding and to combat disease. Lancet Infect Dis. (2011) 11:45-56. doi: 10.1016/S1473-3099(10)70186-9

63. D'arc M, Ayouba A, Esteban A, Learn GH, Boue V, Liegeois F, et al. Origin of the HIV-1 group O epidemic in western lowland gorillas. Proc Natl Acad Sci USA. (2015) 112:E1343-52. doi: 10.1073/pnas.1502022112 
64. Johnson PR, Hirsch VM. SIV infection of macaques as a model for AIDS pathogenesis. Int Rev Immunol. (1992) 8:55-63. doi: 10.3109/08830189209056641

65. Stacey AR, Norris PJ, Qin L, Haygreen EA, Taylor E, Heitman J, et al. Induction of a striking systemic cytokine cascade prior to peak viremia in acute human immunodeficiency virus type 1 infection, in contrast to more modest and delayed responses in acute hepatitis $\mathrm{B}$ and $\mathrm{C}$ virus infections. $J$ Virol. (2009) 83:3719-33. doi: 10.1128/JVI.01844-08

66. Keating SM, Heitman JW, Wu S, Deng X, Stacey AR, Zahn RC, et al. Magnitude and quality of cytokine and chemokine storm during acute infection distinguish nonprogressive and progressive simian immunodeficiency virus infections of nonhuman primates. J Virol. (2016) 90:10339-50. doi: 10.1128/JVI.01061-16

67. Kwon DS, Angin M, Hongo T, Law KM, Johnson J, Porichis F, et al. CD4+ CD25+ regulatory T cells impair HIV-1-specific CD4 T cell responses by upregulating interleukin-10 production in monocytes. J Virol. (2012) 86:6586-94. doi: 10.1128/JVI.06251-11

68. Brooks DG, Trifilo MJ, Edelmann KH, Teyton L, Mcgavern DB, Oldstone MB. Interleukin-10 determines viral clearance or persistence in vivo. Nat Med. (2006) 12:1301-9. doi: 10.1038/nm1492

69. Mylvaganam GH, Chea LS, Tharp GK, Hicks S, Velu V, Iyer SS, et al. Combination anti-PD-1 and antiretroviral therapy provides therapeutic benefit against SIV. JCI Insight (2018) 3:122940. doi: $10.1172 /$ jci.insight.122940

70. Pan E, Feng F, Li P, Yang Q, Ma X, Chunxiu WU, et al. Immune protection of SIV challenge by PD-1 blockade during vaccination in rhesus monkeys. Front Immunol. (2018) 9:2415. doi: 10.3389/fimmu.2018.02415

71. Lifson JD, Nowak MA, Goldstein S, Rossio JL, Kinter A, Vasquez G, et al. The extent of early viral replication is a critical determinant of the natural history of simian immunodeficiency virus infection. J Virol. (1997) 71:9508-14.

72. Huang X, Liu X, Meyers K, Liu L, Su B, Wang P, et al. Cytokine cascade and networks among MSM HIV seroconverters: implications for early immunotherapy. Sci Rep. (2016) 6:36234. doi: 10.1038/srep36234

73. Roberts L, Passmore JA, Williamson C, Little F, Bebell LM, Mlisana K, et al. Plasma cytokine levels during acute HIV-1 infection predict HIV disease progression. AIDS (2010) 24:819-31. doi: 10.1097/QAD.0b013e3283367836

74. Mcmichael AJ, Borrow P, Tomaras GD, Goonetilleke N, Haynes BF. The immune response during acute HIV-1 infection: clues for vaccine development. Nat Rev Immunol. (2010) 10:11-23. doi: 10.1038/nri2674

75. Kolls JK, Linden A. Interleukin-17 family members and inflammation. Immunity (2004) 21:467-76. doi: 10.1016/j.immuni.2004.08.018

76. Hunt PW. Th17, gut, and HIV: therapeutic implications. Curr Opin HIV AIDS (2010) 5:189-93. doi: 10.1097/COH.0b013e32833647d9

77. Macal M, Sankaran S, Chun TW, Reay E, Flamm J, Prindiville TJ, et al. Effective CD4+ T-cell restoration in gut-associated lymphoid tissue of HIV-infected patients is associated with enhanced Th17 cells and polyfunctional HIV-specific T-cell responses. Mucosal Immunol. (2008) 1:475-88. doi: 10.1038/mi.2008.35

78. Ponte R, Mehraj V, Ghali P, Couedel-Courteille A, Cheynier R, Routy JP. Reversing gut damage in HIV infection: using non-human primate models to instruct clinical research. EBioMed. (2016) 4:40-9. doi: 10.1016/j.ebiom.2016.01.028

79. Hahn BH, Shaw GM, De Cock KM, Sharp PM. AIDS as a zoonosis: scientific and public health implications. Science (2000) 287:607-14. doi: 10.1126/science.287.5453.607

80. Silvestri G, Paiardini M, Pandrea I, Lederman MM, Sodora DL. Understanding the benign nature of SIV infection in natural hosts. J Clin Invest. (2007) 117:3148-54. doi: 10.1172/JCI33034

81. Kornfeld C, Ploquin MJ, Pandrea I, Faye A, Onanga R, Apetrei C, et al. Antiinflammatory profiles during primary SIV infection in African green monkeys are associated with protection against AIDS. J Clin Invest. (2005) 115:1082-91. doi: 10.1172/JCI23006

82. Jacquelin B, Mayau V, Targat B, Liovat AS, Kunkel D, Petitjean G, et al. Nonpathogenic SIV infection of African green monkeys induces a strong but rapidly controlled type I IFN response. J Clin Invest. (2009) 119:3544-55. doi: $10.1172 /$ JCI40093

83. Jacquelin B, Petitjean G, Kunkel D, Liovat AS, Jochems SP, Rogers KA, et al. Innate immune responses and rapid control of inflammation in African green monkeys treated or not with interferon-alpha during primary SIVagm infection. PLoS Pathog. (2014) 10:e1004241. doi: 10.1371/journal.ppat.1004241

84. Palesch D, Bosinger SE, Tharp GK, Vanderford TH, Paiardini M, Chahroudi A, et al. Sooty mangabey genome sequence provides insight into AIDS resistance in a natural SIV host. Nature (2018) 553:77-81. doi: 10.1038/nature25140

85. Brenchley JM, Price DA, Schacker TW, Asher TE, Silvestri G, Rao S, et al. Microbial translocation is a cause of systemic immune activation in chronic HIV infection. Nat Med. (2006) 12:1365-71. doi: 10.1038/nm1511

86. Brenchley JM, Douek DC. HIV infection and the gastrointestinal immune system. Mucosal Immunol. (2008) 1:23-30. doi: 10.1038/mi.2007.1

87. Silvestri G, Sodora DL, Koup RA, Paiardini M, O'neil SP, Mcclure HM, et al. Nonpathogenic SIV infection of sooty mangabeys is characterized by limited bystander immunopathology despite chronic high-level viremia. Immunity (2003) 18, 441-452. doi: 10.1016/S1074-7613(03)00060-8

88. Brenchley JM, Paiardini M, Knox KS, Asher AI, Cervasi B, Asher TE, et al. Differential Th17 CD4 T-cell depletion in pathogenic and nonpathogenic lentiviral infections. Blood (2008) 112:2826-35. doi: 10.1182/blood-2008-05-159301

89. Naidu YM, Kestler HW III, Li Y, Butler CV, Silva DP, Schmidt DK, et al. Characterization of infectious molecular clones of simian immunodeficiency virus (SIVmac) and human immunodeficiency virus type 2: persistent infection of rhesus monkeys with molecularly cloned SIVmac. J Virol. (1988) 62:4691-6.

90. Mckay PF, Barouch DH, Schmitz JE, Veazey RS, Gorgone DA, Lifton MA, et al. Global dysfunction of CD4 T-lymphocyte cytokine expression in simian-human immunodeficiency virus/SIV-infected monkeys is prevented by vaccination. J Virol. (2003) 77:4695-702. doi: 10.1128/JVI.77.8.4695-4702.2003

91. Giavedoni LD, Velasquillo MC, Parodi LM, Hubbard GB, Hodara VL. Cytokine expression, natural killer cell activation, and phenotypic changes in lymphoid cells from rhesus macaques during acute infection with pathogenic simian immunodeficiency virus. J Virol. (2000) 74:1648-57. doi: 10.1128/JVI.74.4.1648-1657.2000

92. Ponte R, Rancez M, Figueiredo-Morgado S, Dutrieux J, Fabre-Mersseman V, Charmeteau-De-Muylder B, et al. Acute simian immunodeficiency virus infection triggers early and transient interleukin-7 production in the gut, leading to enhanced local chemokine expression and intestinal immune cell homing. Front Immunol. (2017) 8:588. doi: 10.3389/fimmu.2017.00588

93. El-Serag HB. Epidemiology of viral hepatitis and hepatocellular carcinoma. Gastroenterology (2012) 142:1264-73.e1. doi: 10.1053/j.gastro.2011.12.061

94. Walker CM. Comparative features of hepatitis $C$ virus infection in humans and chimpanzees. Springer Semin Immunopathol. (1997) 19:85-98. doi: 10.1007/BF00945027

95. Guidotti LG, Rochford R, Chung J, Shapiro M, Purcell R, Chisari FV. Viral clearance without destruction of infected cells during acute HBV infection. Science (1999) 284:825-9. doi: 10.1126/science.284.5415.825

96. Lanford RE, Bigger C, Bassett S, Klimpel G. The chimpanzee model of hepatitis C virus infections. ILAR J. (2001) 42:117-26. doi: 10.1093/ilar.42.2.117

97. Thimme R, Wieland S, Steiger C, Ghrayeb J, Reimann KA, Purcell RH, et al. $\mathrm{CD} 8(+) \mathrm{T}$ cells mediate viral clearance and disease pathogenesis during acute hepatitis B virus infection. J Virol. (2003) 77:68-76. doi: 10.1128/JVI.77.1.68-76.2003

98. Apolinario A, Majano PL, Lorente R, Nunez O, Clemente G, GarciaMonzon C. Gene expression profile of T-cell-specific chemokines in human hepatocyte-derived cells: evidence for a synergistic inducer effect of cytokines and hepatitis C virus proteins. J Viral Hepat. (2005) 12:27-37. doi: 10.1111/j.1365-2893.2005.00540.x

99. Akbar H, Idrees M, Butt S, Awan Z, Sabar MF, Rehaman I, et al. High baseline interleukine- 8 level is an independent risk factor for the achievement of sustained virological response in chronic HCV patients. Infect Genet Evol. (2011) 11:1301-5. doi: 10.1016/j.meegid.2011.04.021

100. Zekri AR, Bahnassy AA, Mohamed WS, Alam El-Din HM, Shousha HI, Zayed N, et al. Dynamic interplay between CXCL levels in chronic hepatitis C patients treated by interferon. Virol J. (2013) 10:218. doi: $10.1186 / 1743-422 \mathrm{X}-10-218$ 
101. Dunn C, Brunetto M, Reynolds G, Christophides T, Kennedy PT, Lampertico $\mathrm{P}$, et al. Cytokines induced during chronic hepatitis $\mathrm{B}$ virus infection promote a pathway for NK cell-mediated liver damage. J Exp Med. (2007) 204:667-80. doi: 10.1084/jem.20061287

102. Fletcher NF, Sutaria R, Jo J, Barnes A, Blahova M, Meredith LW, et al. Activated macrophages promote hepatitis C virus entry in a tumor necrosis factor-dependent manner. Hepatology (2014) 59:1320-30. doi: 10.1002/hep. 26911

103. Fletcher NF, Clark AR, Balfe P, Mckeating JA. TNF superfamily members promote hepatitis C virus entry via an NF-kappaB and myosin light chain kinase dependent pathway. J Gen Virol. (2017) 98:405-12. doi: 10.1099/jgv.0.000689

104. Poovorawan K, Tangkijvanich P, Chirathaworn C, Wisedopas N, Treeprasertsuk S, Komolmit P, et al. Circulating cytokines and histological liver damage in chronic hepatitis B infection. Hepat Res Treat. (2013) 2013:757246. doi: 10.1155/2013/757246

105. Deshpande V, Burd E, Aardema KL, Ma CK, Moonka DK, Brown KA, et al. High levels of hepatitis C virus RNA in native livers correlate with the development of cholestatic hepatitis in liver allografts and a poor outcome. Liver Transpl. (2001) 7:118-24. doi: 10.1053/jlts.2001.21278

106. Wald O, Weiss ID, Galun E, Peled A. Chemokines in hepatitis C virus infection: pathogenesis, prognosis and therapeutics. Cytokine (2007) 39:5062. doi: 10.1016/j.cyto.2007.05.013

107. Dienstag JL, Popper H, Purcell RH. The pathology of viral hepatitis types A and B in chimpanzees. A comparison Am J Pathol. (1976) 85:131-48.

108. Lucifora J, Vincent IE, Berthillon P, Dupinay T, Michelet M, Protzer U, et al. Hepatitis B virus replication in primary macaque hepatocytes: crossing the species barrier toward a new small primate model. Hepatology (2010) 51:1954-60. doi: 10.1002/hep.23602

109. De Carvalho Dominguez Souza BF, Konig A, Rasche A, De Oliveira Carneiro I, Stephan N, Corman VM, et al. A novel hepatitis B virus species discovered in capuchin monkeys sheds new light on the evolution of primate hepadnaviruses. J Hepatol. (2018) 68:1114-22. doi: 10.1016/j.jhep.2018.01.029

110. Beames B, Chavez D, Lanford RE. GB virus $B$ as a model for hepatitis $C$ virus. ILAR J. (2001) 42:152-60. doi: 10.1093/ilar.42.2.152

111. Iwasaki Y, Mori K, Ishii K, Maki N, Iijima S, Yoshida T, et al. Longterm persistent GBV-B infection and development of a chronic and progressive hepatitis C-like disease in marmosets. Front Microbiol. (2011) 2:240. doi: $10.3389 /$ fmicb.2011.00240

112. Beames B, Chavez D, Guerra B, Notvall L, Brasky KM, Lanford RE. Development of a primary tamarin hepatocyte culture system for GB virusB: a surrogate model for hepatitis C virus. J Virol. (2000) 74:11764-72. doi: 10.1128/JVI.74.24.11764-11772.2000

113. Woollard DJ, Haqshenas G, Dong X, Pratt BF, Kent SJ, Gowans EJ. Virusspecific T-cell immunity correlates with control of GB virus B infection in marmosets. J Virol. (2008) 82:3054-60. doi: 10.1128/JVI.01153-07

114. Manickam C, Rajakumar P, Wachtman L, Kramer JA, Martinot AJ, Varner $\mathrm{V}$, et al. Acute liver damage associated with innate immune activation in a small nonhuman primate model of hepacivirus infection. J Virol. (2016) 90:9153-62. doi: 10.1128/JVI.01051-16

115. Manickam C, Martinot AJ, Jones RA, Varner V, Reeves RK. Hepatic immunopathology during occult hepacivirus re-infection. Virology (2017) 512:48-55. doi: 10.1016/j.virol.2017.08.037

116. Manickam C, Wachtman L, Martinot AJ, Giavedoni LD, Reeves RK. Metabolic dysregulation in hepacivirus infection of common marmosets (Callithrix jacchus). PLoS ONE (2017) 12:e0170240. doi: 10.1371/journal.pone.0170240

117. Costa F, Sarno M, Khouri R, De Paula Freitas B, Siqueira I, Ribeiro GS, et al. Emergence of congenital Zika syndrome: viewpoint from the front lines. Ann Intern Med. (2016) 164:689-91. doi: 10.7326/M16-0332

118. Azevedo RSS, De Sousa JR, Araujo MTF, Martins Filho AJ, De Alcantara BN, Araujo FMC, et al. In situ immune response and mechanisms of cell damage in central nervous system of fatal cases microcephaly by Zika virus. Sci Rep. (2018) 8:1. doi: 10.1038/s41598-017-17765-5

119. De Sousa JR, Azevedo R, Martins Filho AJ, De Araujo MTF, Cruz E, Vasconcelos BCB, et al. In situ inflammasome activation results in severe damage to the central nervous system in fatal Zika virus microcephaly cases. Cytokine (2018) 111:255-64. doi: 10.1016/j.cyto.2018.08.008

120. De Sousa JR, Azevedo RSS, Martins Filho AJ, Araujo MTF, Moutinho ERC, Baldez Vasconcelos BC, et al. Correlation between apoptosis and in situ immune response in fatal cases of microcephaly caused by Zika virus. Am J Pathol. (2018). doi: 10.1016/j.ajpath.2018.07.009

121. Abbink P, Larocca RA, Dejnirattisai W, Peterson R, Nkolola JP, Borducchi EN, et al. Therapeutic and protective efficacy of a dengue antibody against Zika infection in rhesus monkeys. Nat Med. (2018) 24:721-3. doi: 10.1038/s41591-018-0056-0

122. Abbink P, Stephenson KE, Barouch DH. Zika virus vaccines. Nat Rev Microbiol. (2018). doi: 10.1038/s41579-018-0039-7

123. Alves Dos Santos E, Fink K. Animal models for dengue and zika vaccine development. Adv Exp Med Biol. (2018) 1062:215-39. doi: 10.1007/978-981-10-8727-1_16

124. Adams Waldorf KM, Stencel-Baerenwald JE, Kapur RP, Studholme C, Boldenow E, Vornhagen J, et al. Fetal brain lesions after subcutaneous inoculation of Zika virus in a pregnant nonhuman primate. Nat Med. (2016) 22:1256-9. doi: 10.1038/nm.4193

125. Dudley DM, Van Rompay KK, Coffey LL, Ardeshir A, Keesler RI, BlissMoreau E, et al. Miscarriage and stillbirth following maternal Zika virus infection in nonhuman primates. Nat Med. (2018) 24:1104-7. doi: 10.1038/s41591-018-0088-5

126. Hirsch AJ, Roberts VHJ, Grigsby PL, Haese N, Schabel MC, Wang $\mathrm{X}$, et al. Zika virus infection in pregnant rhesus macaques causes placental dysfunction and immunopathology. Nat Commun. (2018) 9:263. doi: 10.1038/s41467-017-02499-9

127. Martinot AJ, Abbink P, Afacan O, Prohl AK, Bronson R, Hecht JL, et al. Fetal neuropathology in Zika virus-infected pregnant female rhesus monkeys. Cell (2018) 173:1111-22.e10. doi: 10.1016/j.cell.2018.03.019

128. Vanchiere JA, Ruiz JC, Brady AG, Kuehl TJ, Williams LE, Baze WB, et al. Experimental Zika virus infection of neotropical primates. Am J Trop Med Hyg. (2018) 98:173-7. doi: 10.4269/ajtmh.17-0322

129. Aid M, Abbink P, Larocca RA, Boyd M, Nityanandam R, Nanayakkara O, et al. Zika virus persistence in the central nervous system and lymph nodes of rhesus monkeys. Cell (2017) 169:610-20.e14. doi: 10.1016/j.cell.2017. 04.008

130. Appanna R, Wang SM, Ponnampalavanar SA, Lum LC, Sekaran SD. Cytokine factors present in dengue patient sera induces alterations of junctional proteins in human endothelial cells. Am J Trop Med Hyg. (2012) 87:936-42. doi: 10.4269/ajtmh.2012.11-0606

131. Rothman AL. Immunity to dengue virus: a tale of original antigenic sin and tropical cytokine storms. Nat Rev Immunol. (2011) 11:532-43. doi: $10.1038 /$ nri3014

132. Clark KB, Onlamoon N, Hsiao HM, Perng GC, Villinger F. Can non-human primates serve as models for investigating dengue disease pathogenesis? Front Microbiol. (2013) 4:305. doi: 10.3389/fmicb.2013.00305

133. Hickey AC, Koster JA, Thalmann CM, Hardcastle K, Tio PH, Cardosa $\mathrm{MJ}$, et al. Serotype-specific host responses in rhesus macaques after primary dengue challenge. Am J Trop Med Hyg. (2013) 89:1043-57. doi: 10.4269/ajtmh.13-0145

134. Onlamoon N, Noisakran S, Hsiao HM, Duncan A, Villinger F, Ansari AA, et al. Dengue virus-induced hemorrhage in a nonhuman primate model. Blood (2010) 115:1823-34. doi: 10.1182/blood-2009-09-242990

135. Vasconcelos BC, Vieira JA, Silva GO, Fernandes TN, Rocha LC, Viana AP, et al. Antibody-enhanced dengue disease generates a marked CNS inflammatory response in the black-tufted marmoset Callithrix penicillata. Neuropathology (2016) 36:3-16. doi: 10.1111/neup.12229

136. Ferreira MS, De Castro PH, Silva GA, Casseb SM, Dias Junior AG, Rodrigues $\mathrm{SG}$, et al. Callithrix penicillata: a feasible experimental model for dengue virus infection. Immunol Lett. (2014) 158:126-33. doi: 10.1016/j.imlet.2013.12.008

137. Peiris JS, Hui KP, Yen HL. Host response to influenza virus: protection versus immunopathology. Curr Opin Immunol. (2010) 22:475-81. doi: 10.1016/j.coi.2010.06.003

138. Safronetz D, Rockx B, Feldmann F, Belisle SE, Palermo RE, Brining D, et al. Pandemic swine-origin H1N1 influenza A virus isolates show heterogeneous virulence in macaques. J Virol. (2011) 85:1214-23. doi: 10.1128/JVI.01848-10 
139. Liu Q, Zhou YH, Yang ZQ. The cytokine storm of severe influenza and development of immunomodulatory therapy. Cell Mol Immunol. (2016) 13:3-10. doi: 10.1038/cmi.2015.74

140. Teijaro JR, Walsh KB, Cahalan S, Fremgen DM, Roberts E, Scott F, et al. Endothelial cells are central orchestrators of cytokine amplification during influenza virus infection. Cell (2011) 146:980-91. doi: 10.1016/j.cell.2011.08.015

141. Oldstone MB, Teijaro JR, Walsh KB, Rosen H. Dissecting influenza virus pathogenesis uncovers a novel chemical approach to combat the infection. Virology (2013) 435:92-101. doi: 10.1016/j.virol.2012.09.039

142. Margine I, Krammer F. Animal models for influenza viruses: implications for universal vaccine development. Pathogens (2014) 3:845-74. doi: 10.3390/pathogens3040845

143. Skinner JA, Zurawski SM, Sugimoto C, Vinet-Oliphant H, Vinod P, Xue Y, et al. Immunologic characterization of a rhesus macaque $\mathrm{H} 1 \mathrm{~N} 1$ challenge model for candidate influenza virus vaccine assessment. Clin Vaccine Immunol. (2014) 21:1668-80. doi: 10.1128/CVI.00547-14

144. Itoh Y. Translational research on influenza virus infection using a nonhuman primate model. Pathol Int. (2016) 66:132-41. doi: 10.1111/pin.12385

145. Wonderlich ER, Swan ZD, Bissel SJ, Hartman AL, Carney JP, O'malley KJ, et al. Widespread virus replication in alveoli drives acute respiratory distress syndrome in aerosolized H5N1 influenza infection of Macaques. J Immunol. (2017) 198:1616-26. doi: 10.4049/jimmunol.1601770

146. Watanabe T, Iwatsuki-Horimoto K, Kiso M, Nakajima N, Takahashi K, Jose Da Silva Lopes T, et al. Experimental infection of Cynomolgus Macaques with highly pathogenic H5N1 influenza virus through the aerosol route. Sci Rep. (2018) 8:4801. doi: 10.1038/s41598-018-23022-0

147. Rimmelzwaan GF, Kuiken T, Van Amerongen G, Bestebroer TM, Fouchier RA, Osterhaus AD. A primate model to study the pathogenesis of influenza A (H5N1) virus infection. Avian Dis. (2003) 47:931-3. doi: 10.1637/0005-2086-47.s3.931

148. Bruder D, Srikiatkhachorn A, Enelow RI. Cellular immunity and lung injury in respiratory virus infection. Viral Immunol. (2006) 19:147-55. doi: 10.1089/vim.2006.19.147

149. Imai Y, Kuba K, Neely GG, Yaghubian-Malhami R, Perkmann T, Van Loo $\mathrm{G}$, et al. Identification of oxidative stress and Toll-like receptor 4 signaling as a key pathway of acute lung injury. Cell (2008) 133:235-49. doi: 10.1016/j.cell.2008.02.043

150. Cilloniz C, Shinya K, Peng X, Korth MJ, Proll SC, Aicher LD, et al. Lethal influenza virus infection in macaques is associated with early dysregulation of inflammatory related genes. PLoS Pathog. (2009) 5:e1000604. doi: 10.1371/journal.ppat.1000604

151. Kobasa D, Jones SM, Shinya K, Kash JC, Copps J, Ebihara H, et al. Aberrant innate immune response in lethal infection of macaques with the 1918 influenza virus. Nature (2007) 445:319-23. doi: 10.1038/nature05495

152. Baskin CR, Bielefeldt-Ohmann H, Tumpey TM, Sabourin PJ, Long JP, Garcia-Sastre A, et al. Early and sustained innate immune response defines pathology and death in nonhuman primates infected by highly pathogenic influenza virus. Proc Natl Acad Sci USA. (2009) 106:3455-60. doi: 10.1073/pnas.0813234106

153. Moncla LH, Ross TM, Dinis JM, Weinfurter JT, Mortimer TD, Schultz-Darken $\mathrm{N}$, et al. A novel nonhuman primate model for influenza transmission. PLoS ONE (2013) 8:e78750. doi: 10.1371/journal.pone.0078750

154. Jin S, Li Y, Pan R, Zou X. Characterizing and controlling the inflammatory network during influenza A virus infection. Sci Rep. (2014) 4:3799. doi: 10.1038/srep03799

155. Ruebner BH, Hirano T, Slusser RJ, Medearis DNJr. Human cytomegalovirus infection. electron microscopic and histochemical changes in cultures of human fibroblasts Am J Pathol. (1965) 46:477-96.

156. Fiala M, Austin T, Heiner DC, Imagawa DT, Guze LB, Payne JE. Cytomegalovirus infection of polymorphonuclear and mononuclear leukocytes in immunosuppressed transplant patients, patients with CMV mononucleosis and a patient with leukaemia. IARC Sci Publ. (1975) 109-12.

157. Margolis G, Kilham L. Neuronal parasitism and cell fusion in mouse cytomegalovirus encephalitis. Exp Mol Pathol. (1976) 25:20-30. doi: 10.1016/0014-4800(76)90013-7
158. Isom HC. DNA synthesis in isolated hepatocytes infected with herpesviruses. Virology (1980) 103:199-216. doi: 10.1016/0042-6822(80)90138-5

159. Dankner WM, Mccutchan JA, Richman DD, Hirata K, Spector SA. Localization of human cytomegalovirus in peripheral blood leukocytes by in situ hybridization. J Infect Dis. (1990) 161:31-6. doi: 10.1093/infdis/161.1.31

160. Garnett HM. Increased ability of human embryonic fibroblasts to accumulate Ca2+ due to cytomegalovirus infection. Cytobios (1981) 31:107-16.

161. Zhu H, Cong JP, Shenk T. Use of differential display analysis to assess the effect of human cytomegalovirus infection on the accumulation of cellular RNAs: induction of interferon-responsive RNAs. Proc Natl Acad Sci USA. (1997) 94:13985-90. doi: 10.1073/pnas.94.25.13985

162. Kowalik TF, Wing B, Haskill JS, Azizkhan JC, Baldwin ASJr, Huang ES. Multiple mechanisms are implicated in the regulation of NF-kappa B activity during human cytomegalovirus infection. Proc Natl Acad Sci USA. (1993) 90:1107-11. doi: 10.1073/pnas.90.3.1107

163. Waldman WJ, Knight DA, Huang EH, Sedmak DD. Bidirectional transmission of infectious cytomegalovirus between monocytes and vascular endothelial cells: an in vitro model. J Infect Dis. (1995) 171:263-72. doi: 10.1093/infdis/171.2.263

164. Fortunato EA, Mcelroy AK, Sanchez I, Spector DH. Exploitation of cellular signaling and regulatory pathways by human cytomegalovirus. Trends Microbiol. (2000) 8:111-9. doi: 10.1016/S0966-842X(00)01699-1

165. Gerna G, Percivalle E, Baldanti F, Sozzani S, Lanzarini P, Genini E, et al. Human cytomegalovirus replicates abortively in polymorphonuclear leukocytes after transfer from infected endothelial cells via transient microfusion events. J Virol. (2000) 74:5629-38. doi: 10.1128/JVI.74.12.5629-5638.2000

166. Haig DM. Subversion and piracy: DNA viruses and immune evasion. Res Vet Sci. (2001) 70:205-19. doi: 10.1053/rvsc.2001.0462

167. Noriega V, Redmann V, Gardner T, Tortorella D. Diverse immune evasion strategies by human cytomegalovirus. Immunol Res. (2012) 54:140-51. doi: $10.1007 / \mathrm{s} 12026-012-8304-8$

168. Goser S, Ottl R, Brodner A, Dengler TJ, Torzewski J, Egashira K, et al. Critical role for monocyte chemoattractant protein-1 and macrophage inflammatory protein-1alpha in induction of experimental autoimmune myocarditis and effective anti-monocyte chemoattractant protein-1 gene therapy. Circulation (2005) 112:3400-7. doi: 10.1161/CIRCULATIONAHA.105.572396

169. Riou R, Bressollette-Bodin C, Boutoille D, Gagne K, Rodallec A, Lefebvre $\mathrm{M}$, et al. Severe symptomatic primary human cytomegalovirus infection despite effective innate and adaptive immune responses. J Virol. (2017) 91:e02245-16. doi: 10.1128/JVI.02245-16

170. Iwasenko JM, Howard J, Arbuckle S, Graf N, Hall B, Craig ME, et al. Human cytomegalovirus infection is detected frequently in stillbirths and is associated with fetal thrombotic vasculopathy. J Infect Dis. (2011) 203:152633. doi: 10.1093/infdis/jir121

171. Hamilton ST, Scott G, Naing Z, Iwasenko J, Hall B, Graf N, et al. Human cytomegalovirus-induces cytokine changes in the placenta with implications for adverse pregnancy outcomes. PLoS ONE (2012) 7:e52899. doi: 10.1371/journal.pone.0052899

172. Alcendor DJ, Charest AM, Zhu WQ, Vigil HE, Knobel SM. Infection and upregulation of proinflammatory cytokines in human brain vascular pericytes by human cytomegalovirus. J Neuroinflammation (2012) 9:95. doi: 10.1186/1742-2094-9-95

173. Mcgeoch DJ, Cook S, Dolan A, Jamieson FE, Telford EA. Molecular phylogeny and evolutionary timescale for the family of mammalian herpesviruses. J Mol Biol. (1995) 247:443-58. doi: 10.1006/jmbi.1995.0152

174. Swack NS, Liu OC, Hsiung GD. Cytomegalovirus infections of monkeys and baboons. Am J Epidemiol. (1971) 94:397-402. doi: 10.1093/oxfordjournals.aje.a121334

175. Powers C, Fruh K. Rhesus CMV: an emerging animal model for human CMV. Med Microbiol Immunol. (2008) 197:109-15. doi: 10.1007/s00430-007-0073-y

176. London WT, Martinez AJ, Houff SA, Wallen WC, Curfman BL, Traub RG, et al. Experimental congenital disease with simian cytomegalovirus in rhesus monkeys. Teratology (1986) 33:323-31. doi: 10.1002/tera.1420330311

177. Baskin GB. Disseminated cytomegalovirus infection in immunodeficient rhesus monkeys. Am J Pathol. (1987) 129:345-52. 
178. Barry PA, Lockridge KM, Salamat S, Tinling SP, Yue Y, Zhou SS, et al. Nonhuman primate models of intrauterine cytomegalovirus infection. ILAR J. (2006) 47:49-64. doi: 10.1093/ilar.47.1.49

179. Lockridge KM, Zhou SS, Kravitz RH, Johnson JL, Sawai ET, Blewett EL, et al. Primate cytomegaloviruses encode and express an IL-10-like protein. Virology (2000) 268:272-80. doi: 10.1006/viro.2000.0195

180. Striz I, Brabcova E, Kolesar L, Sekerkova A. Cytokine networking of innate immunity cells: a potential target of therapy. Clin Sci. (2014) 126:593-612. doi: $10.1042 / C S 20130497$

181. Cohen BL, Sachar DB. Update on anti-tumor necrosis factor agents and other new drugs for inflammatory bowel disease. BMJ (2017) 357:j2505. doi: 10.1136/bmj.j2505

182. Miller DM, Klucher KM, Freeman JA, Hausman DF, Fontana D, Williams DE. Interferon lambda as a potential new therapeutic for hepatitis C. Ann N Y Acad Sci. (2009) 1182:80-7. doi: 10.1111/j.1749-6632.2009.05241.x

183. Lauw FN, Dekkers PE, Te Velde AA, Speelman P, Levi M, Kurimoto $\mathrm{M}$, et al. Interleukin-12 induces sustained activation of multiple host inflammatory mediator systems in chimpanzees. J Infect Dis. (1999) 179:64652. doi: $10.1086 / 314636$

184. Ansari AA, Mayne AE, Sundstrom JB, Bostik P, Grimm B, Altman JD, et al. Administration of recombinant rhesus interleukin-12 during acute simian immunodeficiency virus (SIV) infection leads to decreased viral loads associated with prolonged survival in SIVmac251-infected rhesus macaques. J Virol. (2002) 76:1731-43. doi: 10.1128/JVI.76.4.1731-1743.2002

185. Waldmann TA, Lugli E, Roederer M, Perera LP, Smedley JV, Macallister RP, et al. Safety (toxicity), pharmacokinetics, immunogenicity, and impact on elements of the normal immune system of recombinant human IL-15 in rhesus macaques. Blood (2011) 117:4787-95. doi: 10.1182/blood-2010-10-311456

186. Degottardi MQ, Okoye AA, Vaidya M, Talla A, Konfe AL, Reyes $\mathrm{MD}$, et al. Effect of Anti-IL-15 administration on T Cell and NK cell homeostasis in rhesus Macaques. J Immunol. (2016) 197:1183-98. doi: 10.4049/jimmunol.1600065

187. Robinson TO, Schluns KS. The potential and promise of IL-15 in immuno-oncogenic therapies. Immunol Lett. (2017) 190:159-68. doi: 10.1016/j.imlet.2017.08.010

188. Hu Q, Ye X, Qu X, Cui D, Zhang L, Xu Z, et al. Discovery of a novel IL-15 based protein with improved developability and efficacy for cancer immunotherapy. Sci Rep. (2018) 8:7675. doi: 10.1038/s41598-01825987-4

189. Ellis-Connell AL, Balgeman AJ, Zarbock KR, Barry G, Weiler A, Egan JO, et al. ALT-803 transiently reduces simian immunodeficiency virus replication in the absence of antiretroviral treatment. J Virol. (2000) 92:e01748-17. doi: 10.1128/JVI.01748-17

190. Romee R, Cooley S, Berrien-Elliott MM, Westervelt P, Verneris MR, Wagner JE, et al. First-in-human phase 1 clinical study of the IL-15 superagonist complex ALT-803 to treat relapse after transplantation. Blood (2018) 131:2515-27. doi: 10.1182/blood-2017-12-823757

191. Wrangle JM, Velcheti V, Patel MR, Garrett-Mayer E, Hill EG, Ravenel JG, et al. ALT-803, an IL-15 superagonist, in combination with nivolumab in patients with metastatic non-small cell lung cancer: a nonrandomised, open-label, phase 1b trial. Lancet Oncol. (2018) 19:694-704. doi: 10.1016/S1470-2045(18)30148-7
192. Barouch DH, Santra S, Schmitz JE, Kuroda MJ, Fu TM, Wagner W, et al. Control of viremia and prevention of clinical AIDS in rhesus monkeys by cytokine-augmented DNA vaccination. Science (2000) 290:48692. doi: $10.1126 /$ science.290.5491.486

193. Henrich TJ, Kuritzkes DR. HIV-1 entry inhibitors: recent development and clinical use. Curr Opin Virol. (2013) 3:51-7. doi: 10.1016/j.coviro.2012.12.002

194. Billick E, Seibert C, Pugach P, Ketas T, Trkola A, Endres MJ, et al. The differential sensitivity of human and rhesus macaque CCR5 to small-molecule inhibitors of human immunodeficiency virus type 1 entry is explained by a single amino acid difference and suggests a mechanism of action for these inhibitors. J Virol. (2004) 78:4134-44. doi: 10.1128/JVI.78.8.4134-4144.2004

195. Este JA, Telenti A. HIV entry inhibitors. Lancet (2007) 370:81-8. doi: 10.1016/S0140-6736(07)61052-6

196. Taaffe JE, Bosinger SE, Del Prete GQ, Else JG, Ratcliffe S, Ward $\mathrm{CD}$, et al. CCR5 blockade is well tolerated and induces changes in the tissue distribution of CCR5+ and CD25+ $\mathrm{T}$ cells in healthy, SIV-uninfected rhesus macaques. J Med Primatol. (2012) 41:24-42. doi: 10.1111/j.1600-0684.2011.00521.x

197. Kelly KM, Tocchetti CG, Lyashkov A, Tarwater PM, Bedja D, Graham $\mathrm{DR}$, et al. CCR5 inhibition prevents cardiac dysfunction in the SIV/macaque model of HIV. J Am Heart Assoc. (2014) 3:e000874. doi: 10.1161/JAHA.114.000874

198. Duffen J, Zhang M, Masek-Hammerman K, Nunez A, Brennan A, Jones JEC, et al. Modulation of the IL-33/IL-13 axis in obesity by IL-13Ralpha2. J Immunol. (2018) 200:1347-59. doi: 10.4049/jimmunol.1701256

199. Yoshizaki K, Nishimoto N, Mihara M, Kishimoto T. Therapy of rheumatoid arthritis by blocking IL-6 signal transduction with a humanized antiIL-6 receptor antibody. Springer Semin Immunopathol. (1998) 20:247-59. doi: 10.1007/BF00832010

200. Rojas JR, Taylor RP, Cunningham MR, Rutkoski TJ, Vennarini J, Jang H, et al. Formation, distribution, and elimination of infliximab and anti-infliximab immune complexes in cynomolgus monkeys. J Pharmacol Exp Ther. (2005) 313:578-85. doi: 10.1124/jpet.104.079277

201. Naidoo J, Page DB, Li BT, Connell LC, Schindler K, Lacouture ME, et al. Toxicities of the anti-PD-1 and anti-PD-L1 immune checkpoint antibodies. Ann Oncol. (2015) 26:2375-91. doi: 10.1093/annonc/mdv383

202. Okoye IS, Houghton M, Tyrrell L, Barakat K, Elahi S. Coinhibitory receptor expression and immune checkpoint blockade: maintaining a balance in CD8(+) $\mathrm{T}$ cell responses to chronic viral infections and cancer. Front Immunol. (2017) 8:1215. doi: 10.3389/fimmu.2017.01215

Conflict of Interest Statement: The authors declare that the research was conducted in the absence of any commercial or financial relationships that could be construed as a potential conflict of interest.

Copyright (C) 2018 Manickam, Shah, Lucar, Ram and Reeves. This is an open-access article distributed under the terms of the Creative Commons Attribution License (CC $B Y)$. The use, distribution or reproduction in other forums is permitted, provided the original author(s) and the copyright owner(s) are credited and that the original publication in this journal is cited, in accordance with accepted academic practice. No use, distribution or reproduction is permitted which does not comply with these terms. 